\title{
KÉTTANNYELVÜSÉG - PEDAGÓGUSKÉPZÉS, KUTATÁS, OKTATÁS C. KONFERENCIA
}

\author{
MÁRKUS ÉVA \\ az Eötvös Loránd Tudományegyetem Tanító- és Óvóképző Karának \\ tanszékvezető föiskolai docense \\ markuseva@t-online.hu
}

Az ELTE TÓFK Idegen Nyelvi és Irodalmi Tanszéke a két tanítási nyelvủ oktatás hazai bevezetésének 20. évfordulója tiszteletére 2008. november 12-én egynapos konferenciát szervezett Kéttannyelvüség - pedagógusképzés, kutatás, oktatás címmel. A konferencia része volt a Magyar Tudomány Hónapja rendezvényeinek. A konferenciát támogatta a Kétnyelvű Iskoláért Egyesület (KIE) és az Óvó- és Tanítóképzők Egyesülete (ÓTE).

Napjainkban egyenletesen növekszik az érdeklődés a két tanítási nyelvü általános iskolai oktatási programok iránt. Az utóbbi években az óvodás korosztály számára is egyre több helyen indítanak nyelvi programokat. A közoktatásnak a fenti igények kielégítése céljából egyre több, erre a speciális területre felkészített pedagógusra van szüksége. Tanító- és óvóképző intézményeink azonban ezekre a feladatokra még csak kevés helyen vannak felkészülve. Az eddig elért eredmények bemutatása mellett a további feladatok megoldásának lehetőségére kerestük a konferencián a választ.

A konferenciát a felsőoktatásban dolgozó kollégák számára szerveztük tapasztalatcsere és összegzés céljával, ennek megfelelőn a résztvevők elsősorban a pedagógusképző intézményekből és a gyakorló óvodákból, illetve iskolákból érkeztek, de jelen volt a Nemzeti Tankönyvkiadó és egy városi önkormányzat képviselője is.

A plenáris ülésen Rádli Katalin (föosztályvezetö-helyettes, Oktatási és Kulturális Minisztérium) A kéttannyelvü tanitásra való felkészités lehetöségei címmel tartott előadást. Szólt az oktatásban történt paradigmaváltásról, hogy a minőségi oktatás kérdése nemzetállami ügyből közösségi szintű feladattá vált, és az oktatás társadalmi, gazdasági funkciója elötérbe került. Felhívta a figyelmet arra, hogy a Nemzeti Alaptantervben meghatározott, kiemelt kulcskompetencia az idegennyelvi kommunikáció. Elmondta, hogy a korai idegennyelv-oktatás ott hatékony, ahol a tanítást olyan pedagógus végzi, aki képzett a korai nyelvtanítás speciális módszertanának elméletében és gyakorlatában. A nyolcvanas évek végén a tanítóképzők e feladat megvalósítására hozták létre az idegennyelv-oktató tanító szakot, amely 1995-től a négyéves tanító szak kötelezően választható idegen nyelvi müveltségi területként élt tovább. Beszélt arról, hogy az idegen-nyelvü kommunikáció kulcskompetencia 
a tanítóképzés tartalmi fejlesztését is szükségessé teszi. A két tanítási nyelvű oktatás nem érheti el a célját, ha csupán a tantárgyak célnyelven folyó oktatása történik. Meg kell, hogy jelenjen az adott korosztályhoz való értés; az oktatás, nevelés szemléletében, módszerében a különböző kultúrák értékein keresztül történő nevelés; az idegennyelven való gondolkodás képességének fejlesztése. Az előadó végezetül ismertette a két tanítási nyelvű oktatás személyi feltételeinek biztosításához jelenleg rendelkezésre álló képzési lehetőségeket. Ezek a tanítói alapképzés idegennyelvi müveltségi területe, a tanítói alapképzési szak nemzetiségi szakiránya valamint az idegennyelv szakos tanári képzés. Új minőséget képviselhet a tanítóképzés kisgyermekkori nyelvi fejlesztésére épülö, tervezett mesterképzési szak: a korai inkluzív nyelvfejlesztő mesterképzési szak. A két tanítási nyelvü iskolai oktatás feltételeinek megteremtése mind a közoktatás, mind a pedagógusképzés oldaláról komoly kihívást jelent.

Vámos Ágnes (egyetemi docens, ELTE PPK; a Kétnyelvü Iskoláért Egyesület elnöke) A két tanitási nyelvü oktatás alapkérdései címmel tartott plenáris előadást. Előadásában vázolta a tannyelvpolitika - tannyelvpedagógia alapkérdéseit: a nyolcvanas években Lewis (1981) és Nahir (1988) a kétnyelvü oktatással kapcsolatosan a nyelvpolitikát mint Policies for Bilingual Education írták le, jelezve, hogy a nyelvpolitikának erre is hatása van. A nyelvpolitikának azon területei, amelyek a tanítás nyelvével kapcsolatosak, a tannyelvpolitika körébe tartoznak. Miként a nyelvpolitika és a nyelvpedagógia, úgy a tannyelvpolitika és a tannyelvpedagógia is kapcsolódik egymáshoz. A szándékolt hatást ugyanis pedagógiai eszközökkel lehet elérni. Ez esetben a tanítás nyelvének pedagógiai jelenségvilága az érdeklődés tárgya, vagyis a tannyelv és más nyelvek kapcsolata, az óraszámok kérdése, a tannyelv és a tantárgyak kapcsolata, a nyelvhasználat, a nyelvváltás stb. Az előadó ezek összefüggéseire tért ki.

Szuchy Gabriella (adjunktus, ELTE TÓFK) szólt a HEFOP keretében történt tartalmi fejlesztésekröl A pedagógusképzés tartalmi és szerkezeti fejlesztése, a HEFOP3.3.1-P-2004-09-0150/1.0 nyelvi programjai című plenáris előadásában. Szó esett arról, hogy a pályázat során kidolgozásra került idegennyelv (német-angol) szakirány a tanító szakon belül az idegennyelvi müveltségterületi képzés lehetőségein túl olyan szakirányos szakosodási lehetőséget biztosít a hallgatóknak, amelynek keretében az idegennyelvi, kulturális, irodalmi és történelmi ismeretek, valamint a szaktantárgyak idegen nyelven történő oktatásának nyelvi és módszertani ismeretei együttesen biztosítják a közoktatás és a társadalom igényeire válaszolni képes nyelvtanító/pedagógus képzését. A virtuális program keretében a tartalmi megújulást az új szempontok érvényesítése biztosította. Középpontba került az oktató-nevelö munkához nélkülözhetetlen pedagógusi személyiség és attitüd kialakítása és a szakmai kompetenciák megalapozása. Hangsúlyosan jelenik meg a program tartalmában a felkészítés az európai térségben való tájékozódásra és más kultúrák megismerésére, elfogadására. Megjelent az esélyegyenlőség és a speciális igényü nyelvtanulók 
oktatására, nevelésére való felkészítés. A program a hagyományos ismeretanyagot a közoktatásban hiányt jelentő ismeretanyaggal egészíti ki.

Kovács Judit (föiskolai docens, ELTE TÓFK, a KIE tudományos szekciójának vezetöje) az ELTE TÓFK magyar-angol kéttannyelvü tanitó- és óvodapedagógus képzési programja címü plenáris előadása a korai idegennyelv-fejlesztésnek egy, a felsőoktatásban mindez ideig kevés figyelmet kapott területéről, a 3-10 éves korosztály nyelvelsajátításon alapuló idegennyelvi programjaira való pedagógusképzésről számolt be. Az ELTE TÓFK-on a 2006/07-es tanévtől kezdve van módja az óvodapedagógus és tanító szakos hallgatóknak ilyen témájú kurzusok választására. Az előadó először röviden áttekintette a korai nyelvfejlesztést támogató pedagógiai-pszichológiai érveket, ezek sorában is különösen azokat, amelyek a korai kezdés és a tartalomalapú nyelvoktatás együttes megvalósítása mellett szólnak. Ezután a témát európai kontextusba helyezte, megjegyezve, hogy korai kéttannyelvü programok Európában mindössze hét országban vannak. A nemzetközi összehasonlításban hazánk igen előkelő helyet foglal el, ezt bizonyították az előadás során bemutatott kutatási eredmények. Az előadás második részében Kovács Judit ismertette az ELTE TÓFK innovációjának, a tartalomalapú általános iskolai, illetve óvodai idegennyelvi programokra felkészítő pedagógusképzésnek a főbb tartalmi jegyeit, amely kurzusokban programíróként és oktatóként vesz részt.

Márkus Éva (tanszékvezető föiskolai docens, ELTE TÓFK) az ELTE TÓFK magyar-német kéttannyelvü tanitó- és óvodapedagógus képzési programja címü plenáris előadásában bemutatásra kerültek az ELTE TÓFK magyar-német kéttannyelvű tanító- és óvodapedagógus képzési programjai: a tanító német mủveltségi terület és a német nemzetiségi tanítóképző program, valamint a német nemzetiségi óvodapedagógus képző program, illetve ezek továbbképzésként felkínált változatai, a német nemzetiségi tanító, illetve német nemzetiségi óvodapedagógus szakirányú továbbképzési szak - már végzett pedagógusok számára. Szó esett ezen kívül az európai dimenzióról a pedagógusképzésben. Az EU-ban minden gyereknek lehetöséget kell teremteni arra, hogy már korai szakaszban megtanuljanak az anyanyelvükön kívül még 2 másik idegen nyelvet. Ezt a célt nem lehet úgy elérni, hogy a gyerekeink az 5. osztályban kezdenek nyelvet tanulni, vagy hogy alsó tagozaton heti 1-2 órában kezdenek nyelvet „tanulni”. Az előadásban szó esett a korai kéttannyelvű oktatás sajátosságairól és a német nyelvterület tapasztalatairól, az immerziós (= a nyelvi belemerítés, nyelvi fürdő) módszerről. Végezetül megfogalmazódott, hogy törekedni kell a kétnyelvű pedagógusképzés bevezetésére, hogy a felsőoktatás kielégíthesse a közoktatás részéről jelentkező igényt: olyan tanítókat kellene képezni, akik képesek az idegen nyelvet nemcsak idegennyelvként tanítani, hanem bizonyos tantárgyakat is képesek idegennyelven tanítani. 
A délutáni szekcióelőadások 4 témacsoport köré rendeződtek:

1. A kisgyermekkori nyelvoktatás kutatásának legújabb eredményei. Módszertani fejlesztés, tananyagfejlesztés a kéttannyelvü pedagógusképzés és a közoktatás számára. A szekciót vezette: Kovács Judit

2. A közoktatási kéttannyelvü gyakorlattal adekvát idegen nyelvü tantárgypedagógiai képzés a felsőoktatásban. A szekciót vezette: Szilágyiné Hodossy Zsuzsanna

3. Pedagógiai és nyelvi kompetenciák a kéttannyelvủ oktatásban. A szekciót vezette: Nádor Orsolya

4. Kéttannyelvü pedagógusképzési programok a magyar/európai felsőoktatásban. A szekciót vezette: Márkus Éva

A konferenciát záró plenáris ülésen a szekcióvezetők összefoglalták szekciójuk tanulságait, a résztvevők elmondhatták véleményüket a konferenciáról, majd Vámos Ágnes szavai zárták a jó hangulatú rendezvényt. A konferencián elhangzott előadások az ELTE TÓFK támogatásával egy konferenciakötetben nyomtatásban is meg fognak jelenni. 